\begin{tabular}{l|l|l|l|l}
\hline Volume 2 & Issue 3 & December (2021) & DOI: 10.47540/ijsei.v2i3.329 & Page: $284-292$ \\
\hline
\end{tabular}

\title{
Post-Harvest Handling and Losses of Green Chilies: A Case Study from Bhutan
}

\author{
Changa Wangmo ${ }^{1}$, Tashi Dendup ${ }^{2}$ \\ ${ }^{1}$ Department of Agriculture, College of Natural Resources, Royal University of Bhutan \\ ${ }^{2}$ Department of Sustainable Development, College of Natural Resources, Royal University of Bhutan
}

Corresponding Author: Tashi Dendup; Email: tashi.cnr@,rub.edu.bt

\begin{tabular}{ll}
\hline A R T I C L E I N F O & A B S T R A C T \\
$\begin{array}{l}\text { Keywords: Chili-production; Chili- } \\
\text { marketing; Post-harvest Activities; }\end{array}$ & $\begin{array}{l}\text { This study assessed post-harvest activities and post-harvest losses of green chili } \\
\text { forming in Kabjisa, Punakha, Bhutan. Data came from interviewing } 75 \text { chili- } \\
\text { growers selected via proportionate random sampling. Most farmers were found } \\
\text { selling fresh chili (green chili). Few farmers produced blanched, dried, and } \\
\text { Received } \quad: 23 \text { August 2021 }\end{array} \quad \begin{array}{l}\text { powdered chilies for self-consumption. Most grown chili varieties were Wookup } \\
\text { ema, Indian chili, and Yangtsep ema. Farmers mostly harvested chilies manually } \\
\text { Accepted }: 26 \text { December 2021 } \\
\text { during the daytime in a bucket. The majority of the farmers have sorted and graded } \\
\text { chilies based on disease infection, damaged parts, and size. Chilies are usually } \\
\text { packed and stored for a night before the sale. Most chili losses occurred during } \\
\text { harvesting, followed by marketing and sorting. The price of fresh chilies had to } \\
\text { discount significantly during the peak season as farmers could not process chilies } \\
\text { into other products. Hence, supporting farmers with dryer, cold storage, chili value } \\
\text { addition infrastructure, and contract farming would minimize chili losses. }\end{array}$ \\
\end{tabular}

\section{INTRODUCTION}

Chili belongs to the Solanaceae family. Chilies existed only on the American continent until 1492, from where they gradually spread to Argentina. Before 8,000 BC, the Mexican started picking the smaller berries of Capsicum (Kraft et al., 2014). Chilies are one of the earliest domesticated crops from wild species in America (Pickersgill, 2017). Chilies can grow up to $1.5 \mathrm{~m}$ tall. Chili peppers are cultivated in warm climates, and they can be eaten fresh or dried. Chilies are powdered to flavor barbecue, spicy sauces, and hot curry. Some of the varieties of chilies grown in Bhutan are Capsicum annum L, Capsicum frutescens L, Capsicum baccatum L, and Capsicum pubescens Ruiez. \& Pav. (Wangdi et al., 2019).

Chilies are one of the main cash crops in Bhutan (Ghimiray et al., 2019). Chilies are also an ingredient in most local dishes. For instance, one of Bhutan's dishEmaDatsi is prepared with a mixture of chilies and cheese. Bhutanese farmers grow chilies for self-consumption and commercial purposes (Ghimiray et al., 2019). Chilies usually grow at 250 to 2,600 meters above sea level (masl).
Different chilies, such as Sha ema, Baegop ema, and Super solo, are produced in Bhutan. According to Ueda \& Samdrup (2008), chili production increases annually in Bhutan. For instance, chili production in 2016 was 9907 metric tons, 136,06 metric tons in 2017, 7,133 metric tons in 2018, 7,673 metric tons in 2019, and 9,332.93 metric tons in 2020 (Bhutan RNR Statistics, 2019). However, Bhutanese farmers experience post-harvest loss of chilies.

The measurable qualitative and quantitative food loss in the post-harvest system is called postharvest loss. Quantity loss is defined as the loss that results in the amount of product. The quality loss includes the loss that affects the nutrient content, the acceptability of the food by the consumers, and the edibility of the product (Kiaya, 2014). The postharvest system includes activities from harvesting until it reaches consumers (Kiaya, 2014). Postharvest activities include harvesting crops, handling, storing, processing, packaging, transportation, and marketing the produce (Maskey et al., 2021). Post-harvest loss can occur due to changes in quality and the quantity of the crop after 
harvesting. To reduce food insecurity, interventions in post-harvest loss reduction are crucial components. Post-harvest loss occurs because the agricultural products that are freshly harvested are the living thing that breathes and undergoes change during post-harvest handling (Kiaya, 2014).

Post-harvest loss is one of the significant problems in chili production. The cost of postharvest loss is greater than the loss of crops in the field (Bernstorff \& Sangay, 2017). Chili is one of the main cash crops for Bhutanese farmers, but the income generated from chilies decreases due to losses during the post-harvest activities. For instance, most chili growers' incomes are hindered due to post-harvest losses in Bhutan (Bernstorff \& Sangay, 2017). Given the limited studies, this study documented post-harvest activities of green chili farming. The study also measured the post-harvest losses in Kabjisa gewog (block), Punakha district, Bhutan.

\section{MATERIALS AND METHODS Study Area}

The study was conducted in Kabjisa gewog, Punakha. Kabjisa gewog stretches over $206.1 \mathrm{Km}^{2}$ with an altitude ranging from 1300-1800 masl (Punakha Dzongkhag Administration, 2020). Farmers cultivate paddy, maize, wheat, mustard, vegetables, and fruits. The main vegetables grown are chili, tomatoes, beans, and broccoli. Mandarin and guava are popular fruits in the gewog (Punakha Dzongkhag Administration, 2020). There are five chiwogs (sub-blocks) under Kabjisa gewog, including Peteri, Zabesa, Tongshina, EsakhaChortenyingpo, Wookuna, and Serigang. Specifically, data were collected from Wookuna, Serigang, and Zabesa chiwogs because these chiwogs grow chili more abundantly than other chiwogs.

\section{Sample Size and Sampling Technique}

Chili is grown in most parts of the Punakha district; however, this study was conducted in three chiwogs (Wookuna, Serigang, and Zabesa) of Kabjisa gewog, where chilies are grown more abundantly. Therefore, the target population was 149 households of these three chiwogs. Fifty percent of 149 households, i.e., 75 households, were taken as the sample. We employed proportionate random sampling (Table 1) to ensure representative sample households in each of these three chosen chiwogs (sub-blocks).

Table 1. Population and sample of households

\begin{tabular}{|l|c|c|}
\hline Categories & Population & Sample \\
\hline Serigang & 52 & 28 \\
\hline Wookuna & 46 & 24 \\
\hline Zabesa & 51 & 23 \\
\hline Total & $\mathbf{1 4 9}$ & $\mathbf{7 5}$ \\
\hline
\end{tabular}

\section{Data Collection and Analysis}

Face-to-face interviews using the structured questionnaire were employed to collect data from chili growers. The questionnaire was refined to improve its clarity after pre-testing ten farmers in Barp Gewog, Punakha. Ten enumerators were hired and trained to collect data using the designed questionnaire. Before the actual survey, administrative approvals were sought from the Dzongkhag Administration and Gewog Administrations. We also got informed consent from all respondents. For example, farmers were informed about the scope of the study in detail. None of them were forced in any way to participate in this study. The International Business Machines Corporation Statistical Package for the Social Sciences (IBM-SPSS) version 25.0 was used to perform basic descriptive statistics, including means, standard deviations, frequencies, and percentages. Results are presented in figures and tables.

\section{RESULTS AND DISCUSSION Characteristics of Chili Farmers}

Most respondents were females (Table 2). Most men were out of their homes pursuing nonfarming activities during data collection time in winter. Most respondents' ages were between 18-60 years, indicating the engagement of economically active people in chili production. None of the farmers were below 18 years because young people were either in schools or colleges. Most farmers were illiterate $(68 \%)$, partly indicating the disinclination of the educated populace to work on the farm. Pelzom \& Katel (2017) also reported the refusal of Bhutanese youths in farming. Older people are unhealthy and less productive (Tang \& MacLeod, 2006); thus, farmers aged 61 years and above are minimal. Only $40 \%$ of farmers have chili growing experience of more than ten years; 
therefore, $60 \%$ of farmers have started chili farming within the past ten years, indicating that the number of chili growers in Kabjisa gewog has been rising in recent years.

Table 2. Characteristics of chili farmers

\begin{tabular}{|l|l|c|c|}
\hline Variable & Categories & Frequency & Percent \\
\hline \multirow{4}{*}{ Gender } & Male & 18 & 24.00 \\
\cline { 2 - 4 } & Female & 57 & 76.00 \\
\hline \multirow{5}{*}{ Age } & Below 17 & 00 & 00.00 \\
\cline { 2 - 4 } & $18-60$ & 36 & 78.70 \\
\cline { 2 - 4 } & Above 61 & 16 & 21.30 \\
\hline Chili farming experience & Literate & 24 & 32.00 \\
\cline { 2 - 4 } & Illiterate & 51 & 68.00 \\
\cline { 2 - 4 } & $1-5$ years & 16 & 21.30 \\
\cline { 2 - 4 } & 6-10 years & 29 & 38.70 \\
\cline { 2 - 4 } & More than ten years & 30 & 40.00 \\
\hline
\end{tabular}

Farmers in Kabjisa own more wetland than dry land (1.65 acres and 0.23 acres, respectively (Figure 1). Farmers cultivated chilies on the wetland, covering an average of 0.46 acres. However, none of the farmers have grown chili on the dry land. It was a rice-based cropping system, and people grew chilies after paddy. They cultivate chilies in the wetland as they own more wetland than dryland in general. Moreover, farmers noticed better yield from wetland than dryland; it could be due to their practice of flood irrigation. This finding concludes that farmers are mostly smallholders, and they grow chilies on wetlands.

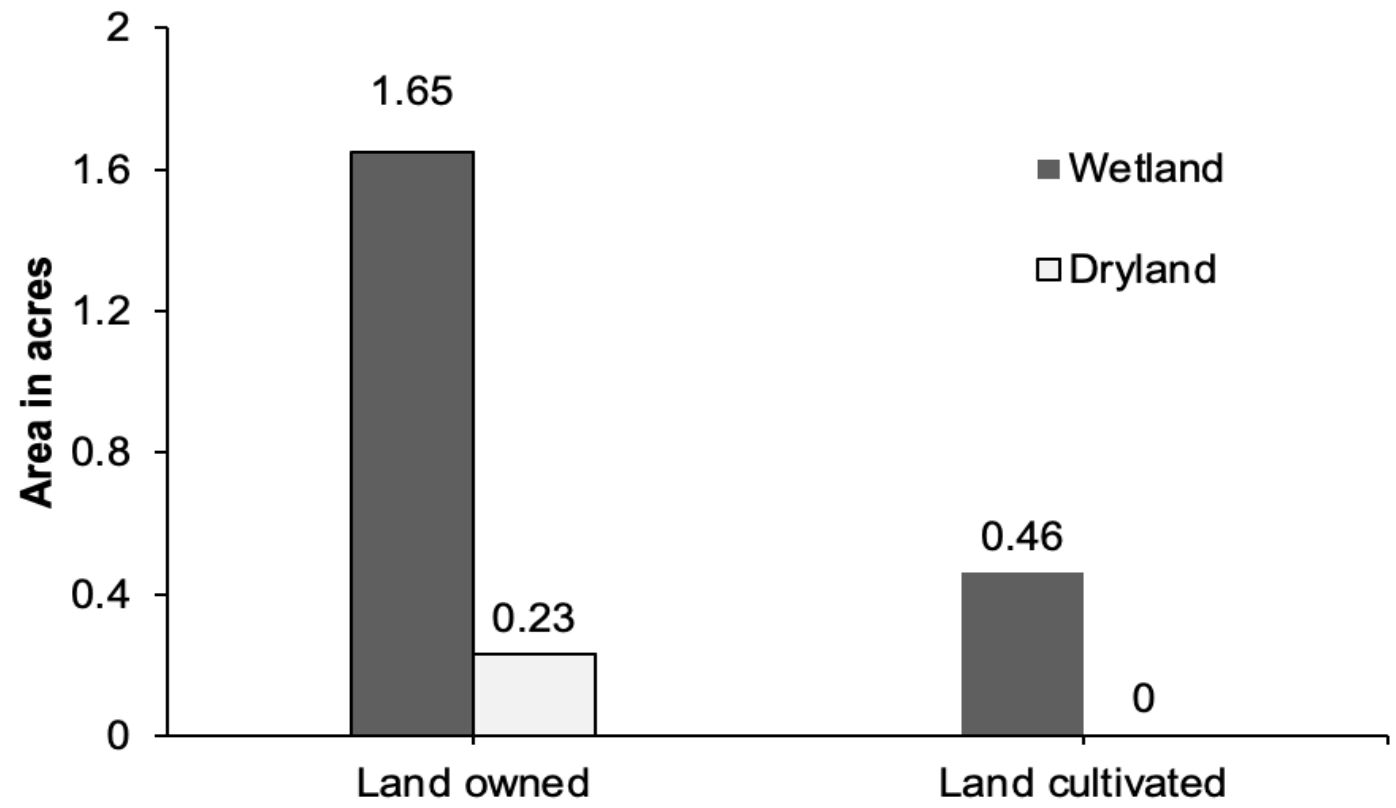

Figure 1. Land owned and cultivated among chili growers

\section{Varieties of Chilies Grown}

The top two chilies in Kabjisa gewog were Wookup ema (94.70\%) and Indian chili (48\%). Farmers mostly preferred these two chilies because of early harvest, multiple harvests, and higher prices. The remaining varieties of chilies (Figure 2) are cultivated primarily for self-consumption purposes as they yield low and cannot be harvested repeatedly. 


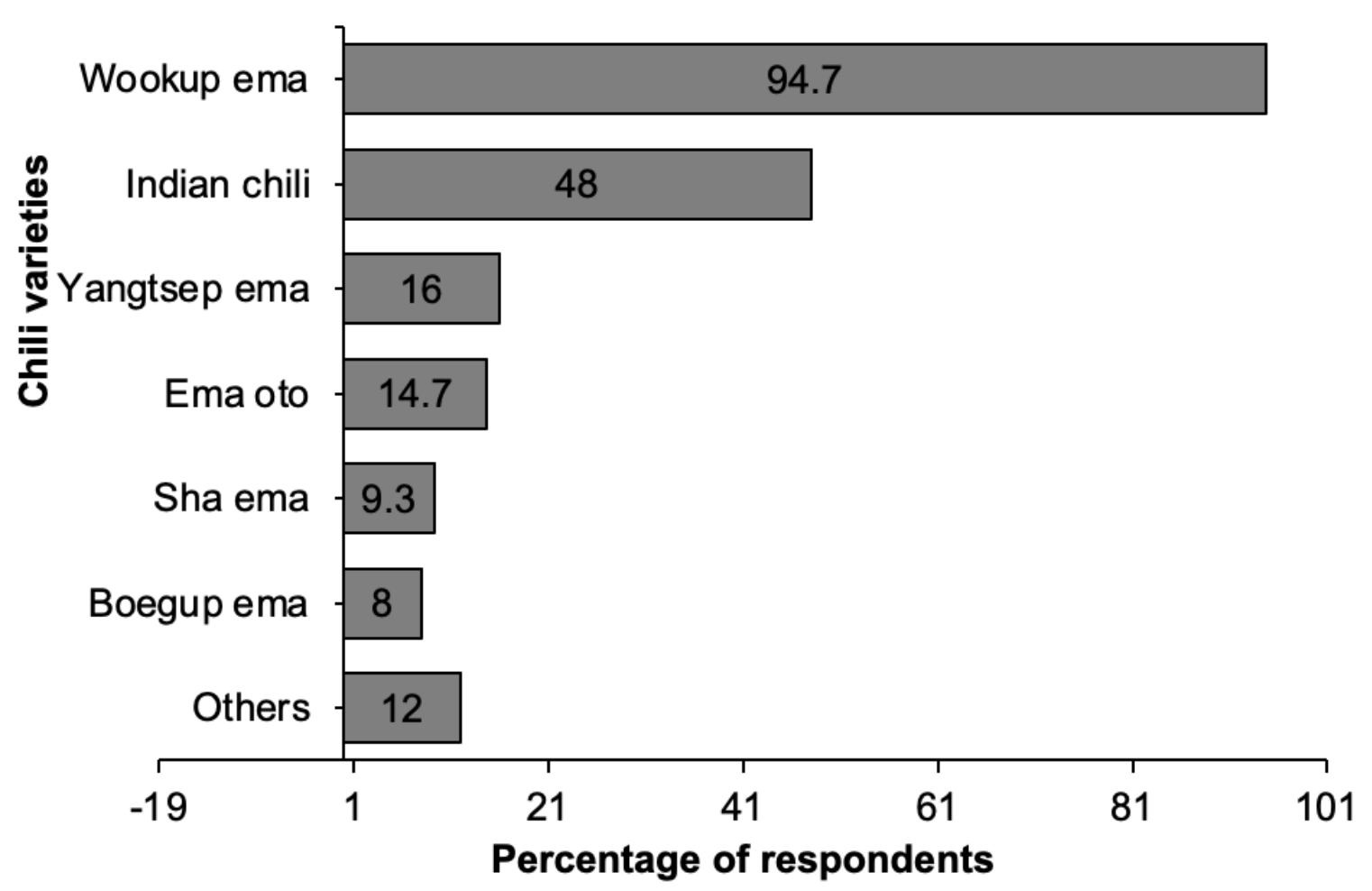

Figure 2. Varieties of chilies grown by farmers in Kabjisa Gewog

\section{Processing of Chilies and Income}

All farmers (100\%) sold fresh chilies without further processing (Table 3). Very few farmers processed blanched chilies $(10.70 \%)$, dry chilies $(9.30 \%)$, and chili powder $(1.30 \%)$. Also, none of the farmers processed chili pickles. Except for a few early harvesters, farmers face bitter competition during the peak production season. Although they could earn a better price for processed chilies, most farmers still sold fresh chilies even at discount rates. The probable reason is that farmers lack infrastructure (e.g., dryers and processing plants for chilies) to dry and store them during the rainy and humid summer season. As drying chilies in humid and rainy places is complex and results in poor quality chilies (Amondi, 2019), this finding implies the need for efficient infrastructures for farmers to pursue the value addition of chilies. Farmers earned an average income of $\mathrm{Nu}$. 194,33 from the sale of fresh chilies (Table 3). No income from other processed chilies indicates that farmers processed a few quantities of chili only for self-consumption.
Table 3. Processing of chilies and income

\begin{tabular}{|l|c|c|}
\hline Processing practices & $\begin{array}{c}\text { Yes } \\
\mathbf{( \% )}\end{array}$ & $\begin{array}{c}\text { Income } \\
\text { (Nu)/year }\end{array}$ \\
\hline Fresh chili & 100.00 & 194,333 \\
\hline Blanched chili & 10.70 & - \\
\hline Dry chili & 9.30 & - \\
\hline Chili powder & 1.30 & - \\
\hline Pickle & 0.00 & - \\
\hline
\end{tabular}

\section{Chili Harvesting}

All farmers (100\%) harvested chili manually (Table 4). Although harvesting chilies with a knife or scissors is considered better (Hicks, 2021), none of the farmers harvested chilies using a knife and scissors because they were unaware of such practice and used to harvesting chilies manually since the olden days. Some farmers (49.30\%) also allowed inexperienced individuals to harvest chilies. Engaging inexperienced people in harvesting and handling could increase post-harvest losses (Maskey et al., 2021). Most farmers (92\%) harvested chilies when it was still in the green stage, followed by looking at the size of chilies $(69.30 \%)$. Although most farmers $(88 \%)$ harvested chilies during the daytime, farmers harvested chilies at any time of the day (Table 4).

The plausible reason is that they are commercial chili growers; they hire laborers to 
harvest many chilies throughout the day. However, it is important to note that normally fresh produce is recommended to harvest during morning hours as the fresh produce can be picked with the dew still on their leaves, which helps retain the product's freshness (Hill, 2021). Some farmers used buckets and bamboo baskets as containers to harvest chilies (Table 4). Some farmers used sacks and plastic bags, increasing the post-harvest losses. Unfortunately, none of the farmers used plastic creates. Thus, agriculture extensions could promote the use of plastic crates because plastic crates are known for reducing post-harvest losses as they are more efficient in handling and transporting (Adegbola et al., 2011).

Table 4. Chili harvesting activities

\begin{tabular}{|l|l|c|c|}
\hline Harvesting & Categories & Frequency & Percent \\
\hline Method & Manual & 75 & 100.00 \\
\hline & Knife & - & - \\
\hline & Scissor & - & - \\
\hline Maturity index & Green & 69 & 92.00 \\
\hline & Size & 52 & 69.30 \\
\hline & Red & 18 & 24.00 \\
\hline & Hard & 57 & 14.70 \\
\hline Harvesting time & Morning & 66 & 76.00 \\
\hline & Daytime & 60 & 88.00 \\
\hline Container use & Evening & 58 & 80.00 \\
\hline & Bucket & 50 & 77.30 \\
\hline & Sack & 02 & 66.70 \\
\hline & Bamboo basket & - & 17.30 \\
\hline Inexperienced harvester & Plastic & 37 & 2.70 \\
\hline
\end{tabular}

\section{Sorting and Grading of Chilies}

Sorting and grading are essential in processing and selling fruits and vegetables (Tiwari et al., 2020). Most farmers $(82.70 \%)$ in Kabjisa also practiced sorting and grading chilies (Table 5). Farmers stated that sorting and grading offer customers choices, thereby making selling easier and fetching better prices than unsorted chilies. Before marketing, farmers sorted and graded chilies based on disease infection $(77.30 \%)$ and damaged parts $(73.30 \%)$. Sorting and grading are crucial because the infected fruits and vegetables spread diseases and produce more ethylene harming the adjacent fruits (Tiwari et al., 2020). However, a few farmers $(17.30 \%)$ did not sort and grade chilies due to time and labor shortage. Overall, most farmers in Kabjisa sort and grade chili for better marketing.
Table 5. Sorting and grading of chilies

\begin{tabular}{|l|l|c|c|}
\hline Variable & Categories & Frequency & Percent \\
\hline Practice & Yes & 62 & 82.70 \\
\cline { 2 - 4 } & No & 13 & 17.30 \\
\hline \multirow{2}{*}{$\begin{array}{l}\text { Sorting } \\
\text { and } \\
\text { grading }\end{array}$} & Color & 29 & 38.70 \\
\cline { 2 - 4 } & Size & 30 & 40.00 \\
\cline { 2 - 4 } & Disease & 58 & 77.30 \\
\cline { 2 - 4 } & Damage & 55 & 73.30 \\
\hline
\end{tabular}

\section{Storage and Packaging}

Most farmers (84\%) stored chilies for only one night (Table 6). Very few farmers stored chilies for more than a night. Infect, $12 \%$ of the farmers did not store chilies as they directly sold them on the same day of harvesting. Farmers stated that storing chili for multiple days resulted in more post-harvest losses due to decay, wilting, and discoloration. Farmers stored chilies in their houses, where there is no adequate temperature, moisture, and ventilation control necessary to minimize the losses during the storage (Tiwari et al., 2020). A study in India also reported the loss of about $0.9 \%$ of chilies during the storage at the farm level (Jha, 2015). 
Thus, farmers sell chilies on the same day of harvest because they do not have to worry about the storage house. Fresh chilies also fetched higher prices in the market; thus, reducing the post-harvest losses.

Lack of immediate transport facilities $(42.70 \%)$ and labor shortages $(33.30 \%)$ were two common reasons for farmers to store chilies (Table 6). Other storage reasons include being unable to sell due to many sellers during the peak season, unavailability of packing materials (e.g., sacks) on time, and delayed by some dealers. Most farmers (93.30\%) packed chilies in sacks to store. Farmers used sacks because they were more accessible and cheaper to buy than other packing materials (e.g., plastic crates). However, chilies kept in bulk or unpacked shriveled rapidly, lost moisture drastically, and lost their freshness and marketable quality (Rahman et al., 2012). Moreover, covering perishable vegetables in plastic or sacks would last only for a day in good quality (Tiwari et al., 2020).

Table 6. Storage and packaging of chilies

\begin{tabular}{|l|l|c|c|}
\hline Variables & Categories & Frequency & Percent \\
\hline Storage & Did not store & 9 & 12.00 \\
\hline & One night & 63 & 84.00 \\
\hline & Two nights & 2 & 02.70 \\
\hline Storing method & Three nights & 1 & 1.30 \\
\hline & Packed & 70 & 93.30 \\
\hline Reason for storing & Unpacked & 5 & 6.70 \\
\hline & Lack of transportation & 32 & 42.70 \\
\hline & Shortage of labor & 25 & 33.30 \\
\hline & Unable to sell & 8 & 10.70 \\
\hline & Others & 7 & 9.30 \\
\hline
\end{tabular}

\section{Transportation and Marketing of Chilies}

All farmers (100\%) transport chilies to markets in personal vehicles or hired vehicles (Table 7) because they often had to transport voluminous chilies to distant markets. Very few farmers $(5.30 \%)$ who sometimes carried chilies on their back to markets were those who reside nearby local markets, who cannot afford the transportation costs, or who do not own a vehicle.

Due to labor shortages and transportation problems, some farmers had to sell chilies within the district (48\%). Most farmers $(65.30 \%)$ sold their chilies for wholesale. Chili dealers either come to farms or take chilies to dealers in the market. Most farmers $(68 \%)$ reported considering consumers' preferences before growing chili as the marketing strategy. For instance, farmers cultivated more Indian chili after the ban of Indian chili in Bhutan. Cultivating varieties of chilies preferred by consumers could be sold quickly and fetched higher prices in the market. About $80 \%$ of farmers sold chilies at discount rates as a marketing strategy, especially during peak production. This finding indicates tough competition among chili growers. However, few farmers $(6.70 \%)$ did not sell chilies at a discount rate; instead, they took them back for self-consumption. 
Table 7. Transportation and marketing of chilies

\begin{tabular}{|l|l|c|c|}
\hline Variables & Categories & Frequency & Percent \\
\hline Transportation mode & Vehicle & 75 & 100.00 \\
\cline { 2 - 4 } & Back & 4 & 5.30 \\
\hline \multirow{3}{*}{ Market } & Outside Dzongkhag & 39 & 52.00 \\
\cline { 2 - 4 } & Within Dzongkhag & 36 & 48.00 \\
\hline \multirow{3}{*}{ Wholesale or retail } & Wholesale & 49 & 65.30 \\
\cline { 2 - 4 } & Retail & 26 & 34.70 \\
\hline Consumers' preferences & Yes & 51 & 68.00 \\
\cline { 2 - 4 } & No & 24 & 32.00 \\
\hline \multirow{4}{*}{ Reason for discount sale } & Many sellers & 65 & 86.70 \\
\cline { 2 - 4 } & No discount sale & 5 & 6.70 \\
\cline { 2 - 4 } & Damaged & 24 & 32.00 \\
\cline { 2 - 4 } & Diseased & & 21.30 \\
\hline
\end{tabular}

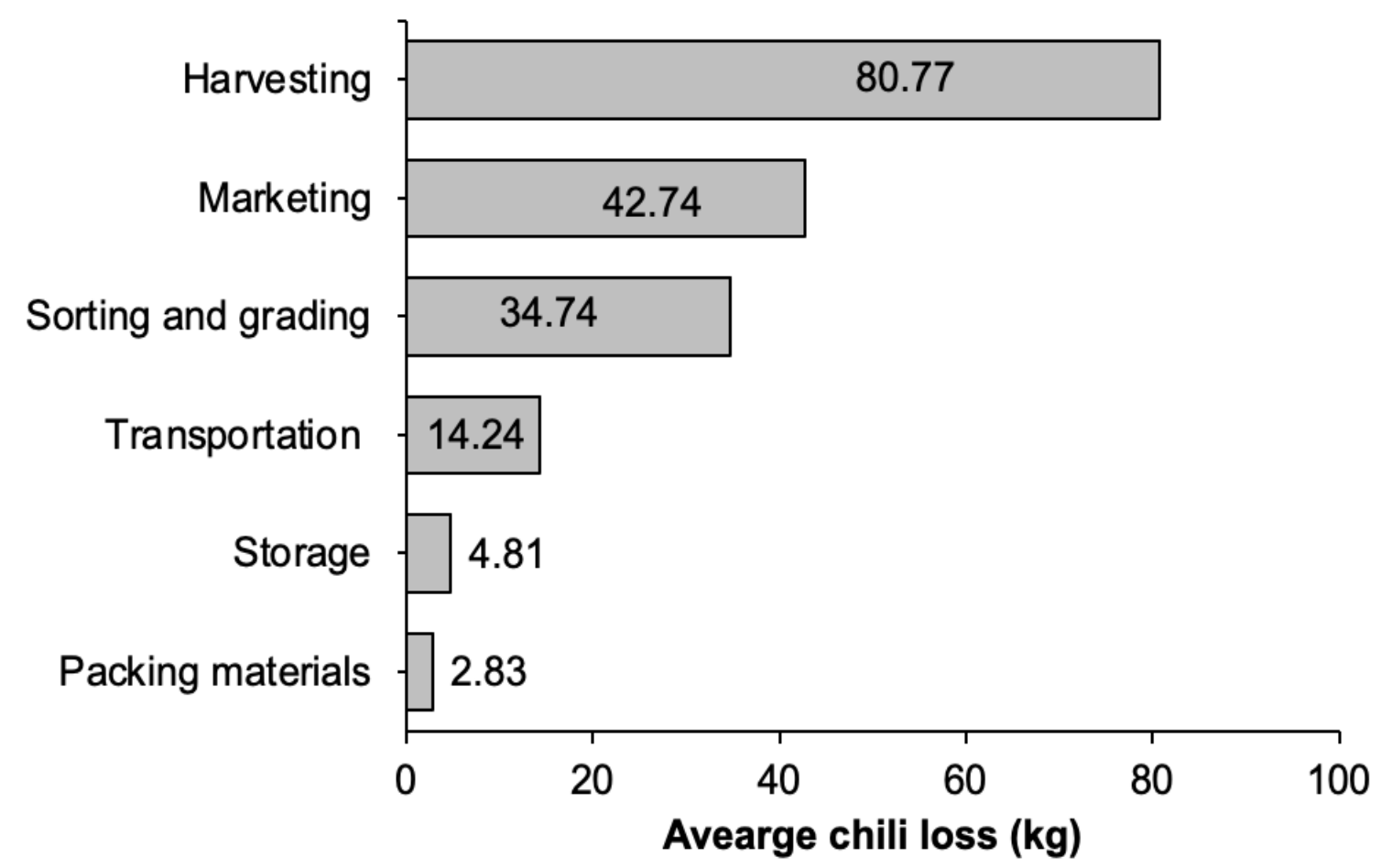

Figure 3. Post-harvest losses of chilies

\section{Post-harvest losses of chilies}

On average, farmers lost $80.77 \mathrm{~kg}$ of chilies annually while harvesting (Figure 3) due to pests and disease, and more heat. Moreover, heavy rainfall during harvesting caused more decay and damage to chilies and chili plants (e.g., breaking of twigs). Lack of proper harvesting container also caused more bruises or damage to chilies. Precooling of chilies extends their shelf life by removing the field heat from chilies (Bhattarai, 2019). However, farmers in Kabjisa did not practice pre-cooling. Instead, they directly packed chilies in sacks and took them to the market or stored it in a storage house, resulting in more post-harvest losses. Farmers were also not getting enough labor while harvesting as harvesting time coincides with paddy plantation. They were also facing challenges like breaking chili twigs while harvesting. Heavy rainfall during harvesting also caused more damage and decay of chilies. The second and third postharvest loss of chilies is during marketing (42.74 $\mathrm{kg}$ ) and sorting and grading $(34.74 \mathrm{~kg})$. Losses during marketing were because of a lack of proper marketplace due to many sellers. For instance, those farmers doing a retail business of chilies often had to display their chilies in the open space during 
weekend markets; thereby, exposing chilies to heat and light, causing more damage. The post-harvest loss also occurred during sorting and grading due to disease and pest infection. Physical injuries due to compaction and bruises during sorting also lost chilies. Along with the issues mentioned above, poor road conditions, inadequate storage facilities, and inferior packing materials also damage chilies.

\section{ConClusion}

This study assessed the post-harvest activities of chilies and measured the post-harvest losses in Punakha, Bhutan. Most farmers harvest green chilies manually at any time of the day. Most farmers sort and grade chilies. Given that there are no cold storage facilities, most farmers store their chilies only for one night. Having cold storage facilities would offer farmers some time to wait until they get the expected price in the market. Most farmers used sacks for packing chilies, causing physical damage due to compactions and heat. Therefore, improved packaging materials, such as plastic crates, could be promoted. Selling chilies in peak production season is changing due to many sellers. Hence, farmers had to sell green chili at a meager price (even at the rate of $\mathrm{Nu} .30 / \mathrm{kg}$ ). Unfortunately, farmers sell only fresh chilies without much value addition. Some farmers who processed chilies into other products (e.g., blanched chili and dry chili) were also only for selfconsumptions. All the challenges mentioned earlier cause post-harvest loss of chilies. Therefore, some of these losses can be prevented if farmers are provided with adequate infrastructures, such as dryers and processing plants for chilies. Additionally, promoting scientific chili farming techniques, climate-resilient (heat, rain, pest, and disease) varieties of chilies, signing the contract with potential large-scale buyers, and efficient transportation facilities (e.g., cold storage delivery van) would further reduce the post-harvest losses.

\section{REFERENCES}

Adeqbola, A., Bamishaiye, I. E., and Olayemi, F. (2011). Factors affecting the re-usable plastic vegetable crate adoption in three local government areas of Kano State, Nigeria. Asian Journal of Agriculture Sciences, 3 (4): 281-285.
Amondi, J. (2019). How to dry chili peppers. Retrieved on 19 April 2021, from http://www.selfup.com.

Bernstorff, A., and Sangay F. (2017). Agricultural sustainability in Bhutan: a perspective. The Druk Journal, 3 (1).

Bhattarai, R. (2019). The effect of hydrocooling, package modification and storage temperature on post-harvest quality of fresh akabare chili (Capsicum chinensis). Retrieved on 24 May 2021, from http://www.202.45.146.37.8080.com.

Bhutan RNR Statistics. (2019). Retrieved on 15 November 2020, from http://www.moaf.gov.bt.com.

Ghimiray, M. (2019). Plant genetic resources in SAARC countries: Their conservation and management. Renewable Natural Resources Research Centre, Bajo.

Hicks, A. (2021). Harvest chili. Retrieved on 19 April 2021, from http://www.chili-plant.com.

Hill, C. (2021). Best time of the day to pick fresh vegetables. Retrieved on 25 December 2021, from http://www.oureverydaylife.com.

Jha S. N., Vishwakarma R. K., Ahmad, T., Rai, A., and Dixit, A. K. (2015). Report on assessment of quantitative harvest and postharvest losses of major crops and commodities in India. ICAR-All India Coordinated Research Project on PostHarvest Technology, ICAR-CIPHET, P.O.PAU, Ludhiana-141004.

Kraft et al. (2014). Multiple lines of evidences for the origin of domesticated chili pepper, Capsicum annuum, in Mexico. Social Sciences, 111 (17): 6165-6170.

Kiaya, V. (2014). Post-harvest losses and strategies to reduce them. Retrieved on 24 May 2021, from http://www.scholar.google.com.

Maskey, B., Bhattarai, R., Bhattarai, G., and Shrestha, K. N. (2021). Post-harvest quality of fresh akabare chili (Capsicum chinese) as affected by hydrocooling, package modification and storage temperature. International Journal of Food Properties, 24 (1): 163-173.

Pelzom, T., and Katel, O. (2017). Youth perception of agriculture and potential for employment in the context of rural development in 
Bhutan. Development, Environment and Foresight, 3 (2): 92-106.

Pickersgill, B. (2017). The domestication of chili peppers. In The domestication and exploitation of plants and animals (pp. 443450). Routledge.

Punakha Dzongkhag Administration. (2020). Retrieved on 11 November 2020, from http://www.punakha.gov.bt.com.

Rahman, M. M., Miaruddin, D. M., Chowdhury, F. G.M., Khan, H. H. M., and Matin, M. (2012). Effect of different packaging system and chlorination on the quality and shelf life of green chili. Bangladesh Journal of Agriculture Research, 37 (4): 729-736.

Tang J., and MacLeod, C. (2006). Labor force ageing and productivity performance in Canada. Canadian Journal of Economics, 39 (2), 582-603.

Tiwari et al. (2020). Post-harvest practices and loss assessment in tomato (Solanum lycopersicum L.) in Kathmandu, Nepal. Journal of Agriculture and Natural Resources, 3(2): 335-352.

Ueda, A., and Samdrup, T. (2008). Chili transactions in Bhutan: An economic, social and cultural perspectives. Retrieved on 19 November 2020, from http://www.himalaya.socanth.cam.ac.uk.com

Wangdi, T., Watcharawetsaringkhan, S., Philadee, J., and Pooprompan, P. (2019). Evaluation of morphological characteristics of Bhutanese landrace chilies (Capsicum spp.). Retrieved on 25 December 2021, from http://www.li01.tci-thaijo.org.com. 